Relations industrielles

Industrial Relations

\title{
Metcalf, David, and Simon Milner, ed., New Perspectives on Industrial Disputes
}

\section{Phil Beaumont}

Volume 49, numéro 3, 1994

URI : https://id.erudit.org/iderudit/050965ar

DOI : https://doi.org/10.7202/050965ar

Aller au sommaire du numéro

Éditeur(s)

Département des relations industrielles de l'Université Laval

ISSN

0034-379X (imprimé)

1703-8138 (numérique)

Découvrir la revue

Citer ce compte rendu

Beaumont, P. (1994). Compte rendu de [Metcalf, David, and Simon Milner, ed., New Perspectives on Industrial Disputes]. Relations industrielles / Industrial Relations, 49(3), 609-611. https://doi.org/10.7202/050965ar

Tous droits réservés @ C Département des relations industrielles de l'Universite Laval, 1994
Ce document est protégé par la loi sur le droit d'auteur. L’utilisation des services d’Érudit (y compris la reproduction) est assujettie à sa politique d'utilisation que vous pouvez consulter en ligne.

https://apropos.erudit.org/fr/usagers/politique-dutilisation/ 
(p. 206)... L'évolution jurisprudentielle probablement la plus significative est du même ordre, qu'il s'agisse, en matière de discrimination sexuelle, du traitement du harcèlement sexuel et des disparités salariales indues (p. 195-196), ou encore, de la discrimination mettant en cause l'orientation sexuelle (p. 198). À cet égard, la prédiction de l'auteur, il y a plus d'une dizaine d'années, d'une certaine croissance de la protection juridique générale de la personne au travail, se révèle juste.

Ce même auteur n'hésite pas d'ailleurs à se montrer critique à l'occasion à l'endroit de diverses solutions jurisprudentielles, qu'il s'agisse en particulier du sort des grévistes remplacés (p. 99), de la distinction entre sujets obligatoires et permissifs de négociation collective (p. 109). Il s'en prend également à l'abstentionnisme d'arbitres de grief lorsqu'il s'agit de l'application de l'interdiction légale de discrimination à l'endroit de l'employeur ou du syndicat (p. 139), de même qu'à certains jugements en la matière, par exemple cet arrêt de la Cour d'appel du cinquième circuit permettant à un employeur d'interdire à des hispanophones de parler entre eux leur langue en présence de clients de langue anglaise de l'entreprise (p. 195).

Globalement, l'auteur continue en conclusion de prédire l'excroissance de la législation directement protectrice et d'ordre public. Ceci pourra, dans une certaine mesure, compenser le déclin marqué, présentement observable, de l'action syndicale traditionnelle. Certes, à ce dernier sujet, certains syndicats s'insèreront-ils dans des formules innovatrices de participation; mais la problématique générale d'une éventuelle redéfinition de l'encadrement juridique de la représentation des salariés aux États-Unis reste en plan. L'auteur, bien conscient de la difficulté (voir sa préface de la présente édition), ne peut l'esquiver en y signalant les succès particuliers de la négociation collective dans le monde du baseball...

Même si nous devons ainsi rester sur notre faim quant à l'orientation future de la représentation des salariés outre-frontière, nous continuons de trouver dans le précis du professeur Gould cette brillante et parfois incisive synthèse des aspects significatifs du droit du travail américain.

Pierre Verge

Université Laval

New Perspectives on Industrial Disputes, by David Metcalf and Simon Milner (ed.), London, Routledge, 1993, 262 p., ISBN 0-415-09151-9.

This edited volume arises out of a conference held at the London School of Economics in 1992. Many conference based books give the impression that participants were primarily attracted by the opportunity to visit a new city, with many of the papers having been written on the plane. It is pleasing to say that this particular volume does not fall into this category. Instead what we have here is a book very much based on contributions from individuals actively involved in various strands of research concerning various aspects of industrial disputes.

The book consists of eleven substantive chapters. The first is a scene-setting one by the editors which highlights the major themes addressed in the individual chapters, 
groups the individual chapters, and identifies some of the leading findings to emerge in each chapter. Broadly the chapters fall into three groupings : three chapters concerning certain characteristics of management and unions associated with industrial disputes; four chapters looking at aspects of dispute deterrence, and two concerned with the consequences of disputes.

The second chapter concentrates on the industrial relations of new plants or greenfield sites where there is held to be greater management potential to avoid the disputes of older establishments. This is essentially a literature review, with no original empirical research being presented. Moreover it is a rather premature literature review in the sense that it is synthesising a very limited body of existing research. As a consequence it is the questions raised, rather than any answers provided, which are the most important aspect of this particular chapter. The third chapter by Dunn and Wright makes more of an original research contribution by revisiting in the early 1990 s large unionised companies and employers' associations which were initially researched in the late 1970 s-early 1980 s. The particular focus of the chapter is on management views concerning the declining presence of closed shop arrangements, with the major general finding being a relatively high level of managerial indifference.

Chapter 4 uses data from the second national Workplace Industrial Relations Survey to examine some of the alleged effects of multi-unionism. This multivariate statistical work by three labour economists essentially indicates that it is fragmented bargaining, rather than multi-unionism as such, which is associated with outcomes such as higher wages, (perceived) inferior financial performance of the establishment, and strikes of more than a day's duration by manual workers. The chapter by Elgar and Simpson provides much more of a legal perspective on disputes. They caution against any simple view that the extensive package of employment legislation in the UK in the 1980 s has produced a straightforward, system-wide reduction in strike activity. Instead their empirical research in four different sectors of employment (education, other public services, printing and publishing, engineering and construction) emphasises that, although the law has in general become a more important factor in industrial relations in the $1980 \mathrm{~s}$, its impact has varied considerably according to sectoral circumstances. The introduction of pre-strike ballots has been the most high profile legal change in the British system of industrial relations in the 1980s. According to the Government, such ballots would enhance union democracy and lower the level of disputes. Chapter 6 utilises economic theories concerning asymmetric information to try and predict the consequences of the introduction of such ballots.

The chapter by Milner utilises a variety of data sources to consider the effect of final offer arbitration arrangements. In general, the conclusion is that such arrangements have not been obviously superior to conventional arbitration in deterring disputes, except where multi-stage dispute procedures are involved. The chapter by Craig Olson provides a comprehensive review of North American research concerning the impact of interest arbitration, with a number of suggestions being offered for future research.

In Chapter 9 the long-standing question of whether 'strikes pay off' is addressed. Utilising information contained in the CBI Pay Databank it is reported that over the 1980 s real pay increases on average were 0.7 per cent a year higher in settlements involving a strike compared to settlements without a strike. Various illustrative 
calculations are then carried out to see how long a strike is worthwhile from the union's viewpoint. The chapter by Richardson and Rubin uses a variety of information sources to examine the nature of the management response to the 1989-90 engineering industry strike concerned with reducing the length of the working week. Their work suggests that management was relatively successful in offsetting the costs of a shorter week by bringing about changes in working practices. The final chapter, which is listed as an appendix, contains a wealth of time series strike information for the UK; specifically new information is presented on a per union member, as opposed to per employee, basis.

With strike levels being well down in advanced industrialised economies, the topic of industrial disputes is not a particularly fashionable or hot one at the moment. This being said, there are many positive things to say about this particular book. Important, enduring, questions are examined, original research is presented, the level of analysis is relatively high, and differing discipline and methodological perspectives and approaches are present. Indeed an 'outsider' who still thinks of UK industrial relations research as being all about single plant, qualitative case studies, would particularly benefit from looking at this book; it would indicate just how much things have changed.

One of my few quibbles with the book would be its title. Useful perspectives, varjed perspectives, worthwhile perspectives? Certainly! New perspectives? Well, maybe it's just a question of semantics.

P. B. Beaumont

\section{University of Glasgow}

Le Québec en jeu : comprendre les grands défis, sous la direction de Gérard DAIGLE avec la collaboration de Guy RoCHER, Montréal, Presses de l'Université de Montréal, 1992, 811 p., ISBN 2-76-06-1594-4.

Pas moins de huit cent onze pages publiées serrées; vingt-huit chapitres regroupés en quatre parties répondant aux titres suivants: «L'Économie et le travail», « Le Social », «Le culturel » et «Le Polique ». Quatre parties soit, mais pourquoi pas une cinquième partie qui aurait traité des «enjeux » et des «défis » d'ordre économique, diplomatique, militaire que posent au Québec d'aujourd'hui son insertion et son appartenance « de fait " à la communauté internationale si dissonante et conflictuelle soitelle ? Faut-il retenir ici le manque de ressources ou faire état d'une approche quelque peu « égocentrique » en ce qu'elle resterait centrée sur la recherche d'une identité collective toujours circonscrite?

Vingt-huit chapitres - ou plutôt vingt-huit articles, nous y reviendrons - dont Gérard Daigle, le maître d'œuvre en les circonstances, nous dit dans l'avant-propos qu'il a rédigé et signé, qu'il s'agit de « textes originaux et intégraux » et non pas « d'extraits d'articles ou de volumes déjà publiés » (p. 19). Il reste, sans démentir ni Gérard Daigle, ni les auteurs de ces vingt-huit chapitres couvrant l'ensemble de la période allant des années soixante à quatre-vingt-douze, tel était l'objectif assigné (p. 17), laissent le lecteur attentif sur une impression de «déjà lu » ou de «déjà entendu ». 